\title{
Determination of Lead in Waste Water Using Cyclic Voltammetry by Platinum Wire Electrode
}

\author{
Riyanto* \\ *Department of Chemistry, Universitas Islam Indonesia, \\ Jalan Kaliurang KM 14,5 Sleman Yogyakarta Indonesia 55584 \\ Corresponding author: Tel: (0274) 896439 ext 3012; Fax: (0274) 896439 \\ E-mail: riyanto@uii.ac.id
}

\begin{abstract}
ABSTRAK
Telah dilakukan penentuan $\mathrm{Pb}$ pada air limbah menggunakan metode siklik voltammetri dengan elektroda batang Pt. Metode siklik voltammetri dilakukan dengan tiga elektroda yaitu elektroda batang Pt sebagai elektroda kerja, elektroda lempeng Pt sebagai elektroda pembanding dan $\mathrm{Ag} / \mathrm{AgCl}(\mathrm{KCl}$ jenuh) sebagai elektroda rujukan. Instrumen yang digunakan yaitu PGSTAT $100 \mathrm{~N} 100 \mathrm{~V} / 250 \mathrm{~mA}$ type (Metrohm Autolab). Elektroanalisis dilakukan dalam larutan elektrolit $0.1 \mathrm{M} \mathrm{KCl}$. Hasil penelitian menunjukkan bahwa analisis $\mathrm{Pb}$ dengan metode siklik voltammetri menghasilkan parameter analisis seperti koefisien korelasi $\mathrm{R}^{2}=0.999, \mathrm{LOD}=0.9029 \mathrm{mg} / \mathrm{L}, \mathrm{LOQ}=3.0098 \mathrm{mg} / \mathrm{L}$ dan recovery $=100,67 \%$. Metode ini sangat sesuai untuk analisis $\mathrm{Pb}$ karena mempunyai parameter analisis yang sangat baik, selain itu metode ini sangat sederhana dan sedikit penggunaan bahan kimia.
\end{abstract}

Kata-kata kunci: $\mathrm{Pb}$, air limbah, siklik voltammetri, batang platinum.

\section{ABSTRACT}

Determination of lead in waste water using cyclic voltammetry by platinum wire electrode has been carried out. The cyclic voltammetry method was performed in a three electrodes system using platinum wire as a working electrode, an $\mathrm{Ag} / \mathrm{AgCl}$ (saturated $\mathrm{KCl}$ ) as reference electrode and platinum plate as the counter electrode. PGSTAT $100 \mathrm{~N} 100 \mathrm{~V} / 250 \mathrm{~mA}$ type (Metrohm Autolab) was used for electroanalysis measurements. Electroanalysis of lead in waste water was performed in $0.1 \mathrm{M} \mathrm{KClas}$ an electrolyte. From this research showed that the developed electroanalysis lead in waste water using platinum wire electrode are accurate, precise, reproducible and inexpensive with acceptable correlation of determination $\left(\mathrm{R}^{2}=0.999\right), \mathrm{LOD}=0.9029 \mathrm{mg} / \mathrm{L}, \mathrm{LOQ}=3.0098 \mathrm{mg} / \mathrm{L}$ and recovery $=100,67 \%$. The methods can be used for the analysis of lead in waste water. This method is simplicity of sample preparation and use of low cost reagents are the additional benefit.

Keywords: lead, wastewater, cyclic voltammetry, platinum wire

\section{Introduction}

Heavy metals such as lead, cadmium

and mercury are rapidly increasing continuously to an alarming level, particularly in rivers and near shore waters where industrial wastes are being discharged. They tend to concentrate in all matrices in the environment (Srivastav et al 1994). Lead is one of the very toxic heavy metals that not only accumulate in individual but also have the ability to affect the entire food chain and disrupt the health system of human beings, animals and phytoplanktons (Singh et al. 2012). Inhuman, it is absorbed directly into 
the blood stream and is stored in soft tissues, bones and teeth (95\% in bones and teeth) (David et al. 2003). It can also affect the kidney and most importantly the nervous system and brain. Thus, lead can accumulate over a lifetime and it causes diseases such as anemia, encephalopathy, hepatitis and nephritic syndrome. It exceeds the WHO (2004) allowable standard $0.15 \mathrm{mg} / \mathrm{L}$ and constant exposure may lead to delay in physical or mental development in infants and children while adults may have kidney problems and high blood pressure. Lead contaminates water by the corrosion of household plumbing system and erosion of natural deposits (US EPA 2005).

Lead is a cumulative poison that enters the body from lead water pipes, lead-based paints and leaded petrol. Presence of even traces of $\mathrm{Pb}(\mathrm{II})$ in environmental samples leads to environmental pollution and many fatal diseases including dysfunction of renal blood and neurological systems. $\mathrm{Pb}$ (II) easily deposits in blood, kidney, reproductive system, nervous system and brain, and acute lead poisoning can result in colic shock, severe anemia and irreversible brain damage. Lead compounds as antiknocking agents in automobile fuels cause air pollution.

So it is very important to find a very sensitive and selective method for the determination of trace levels of lead in the environment. Various methods have been reported for the determination of lead in environmental samples. These methods include resonance light scattering technique (Cui et al 2012) and spectrophotometric methods (Naeem et al. 2012). Different techniques were used for trace lead analysis such as spectroscopic methods especially graphite furnace atomic adsorption spectroscopy (GF-AAS) (Duran et al 2009), and inductively coupled plasma mass spectroscopy (ICP-MS)(Voica et al. 2012). These methods have excellent sensitivity and good selectivity, but have different drawbacks such as time consuming used for analysis and very expensive instruments are required.

Electrochemical methods including cyclic voltammtery have recognized powerful tools for measuring trace analysis. It have shown different advantages such as speed of analysis, higher selectivity and sensitivity, low coast, easy operation and the ability of analyzing element speciation. Different working electrodes were used for the voltammetric determination of lead such as hanging mercury drop electrode (HMDE) (Raj et al.2013), mercury film electrode (Carapuc et al. 2004), graphite electrode (Marichamy and Ramalakshmi 2013), silver 
electrode (Zen et al. 2002) and gold electrode (Laschi et al. 2006).

Chemically modified electrodes have been develop the recent years for the electrochemical determination of heavy metals due to different advantages such as easy manufacture, no poison, renewable, fast response, high selectivity, low detection limit, stable in various solvent, longer life time and low cost.

In the present work a new, simple and precise method is proposed for the determination of lead in environmental samples. The method is based on electrochemical analysis in $\mathrm{KCl}$ solution at room temperature using platinum wire electrode. Platinum wire electrode is the simple and low cost the electrode fabrication, high speed, reproducibility, high stability, wide linear dynamic range and high sensitivity.

\section{Experimental Section}

\section{Materials}

All solutions were prepared by dissolving their analytical grade reagent (Merck) in deionised distilled water. Pt wire and plate (Metrohm Autolab) was used for anode and cathode electrodes. $\mathrm{KCl} 0,1 \mathrm{M}$ was prepared using $\mathrm{KCl}$ (Merck) and aquabidest. $\mathrm{Pb}$ solutions were prepared by dilution of absolute $\mathrm{Pb}$ with Certified Reference Material (CRM) fromMerck with deionised distilled water. The calibration curve was made by using $\mathrm{Pb}$ concentration of $10-100 \mathrm{mg} / \mathrm{L}$.

\section{Waste Water Samples}

Samples of waste water were collected from Center Laboratory, Islamic University of Indonesian, Yogyakarta, Indonesia.

\section{Instrumentation}

$\begin{array}{llllll}\text { PGSTAT } & 100 & \mathrm{~N} & 100 & \mathrm{~V} / 250 & \mathrm{~mA}\end{array}$

(Metrohm Autolab) was used for electroanalysis measurementswhile data acquisition was accomplished by using the Nova software. Instrumentis equipped with three electrodes system using $\mathrm{Pt}$ wire as a working electrode, an $\mathrm{Ag} / \mathrm{AgCl}$ (saturated $\mathrm{KCl})$ as reference electrode and platinum plate as the counter electrode.

\section{Procedure}

\section{Electroanalysis of $\mathbf{P b}$}

The electrochemical process of $\mathrm{Pb}$ was performed in $0.1 \mathrm{M}$ KClsolution at room temperature. The electrochemical studies by cyclic voltammetry $(\mathrm{CV})$ were performed in $50 \mathrm{~mL}$ capacity glass electrochemical cell. The cyclic voltammetry experiments were performed in a three electrodes system using Pt wire as a working electrode, an $\mathrm{Ag} / \mathrm{AgCl}$ 
(saturated $\mathrm{KCl}$ ) as reference electrode and platinum plate as the counter electrode. All potentials given are with respect to the $\mathrm{Ag} / \mathrm{AgCl}$ reference electrode.

\section{Calibration and validation method}

Calibration curves were obtained by plotting anodic peak height (current) versus
$\mathrm{Pb}$ concentration. Validation parameters including linearity, limit of detection (LOD), limit of quantification (LOQ), precision and accuracy were assessed. Cyclic voltammograms $(\mathrm{CVs})$ of $\mathrm{Pb}$ solutions were recorded in a wide range of concentrations $(10-100 \mathrm{mg} / \mathrm{L})$ in $0.1 \mathrm{M} \mathrm{KCl}$ solution at room temperature.

\section{Result And Disscusion}

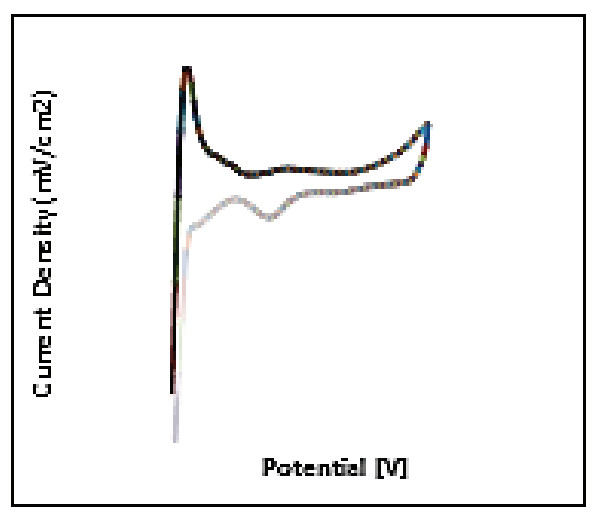

A

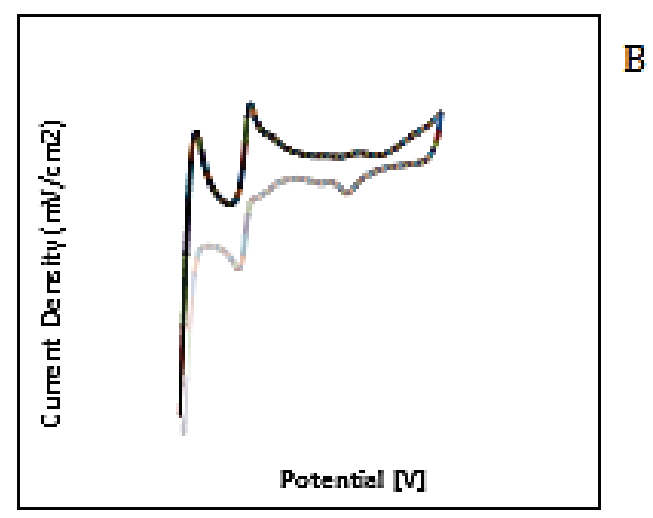

Figure 1. Cyclic voltammograms using Pt wire electrode in (A) $\mathrm{KCl} 0.1 \mathrm{M}$ and (B) $\mathrm{KCl} 0.1$

$$
\mathrm{M}+10 \mu \mathrm{L} \mathrm{Pb}\left(\mathrm{NO}_{3}\right)_{2} 1000 \mathrm{mg} / \mathrm{L} \text { with scan rate } 50 \mathrm{mV} / \mathrm{sec} .
$$

Figure 1 shows cyclic voltammograms using $\mathrm{Pt}$ wire electrode in (A) $\mathrm{KCl} 0.1 \mathrm{M}$ and (B) $\mathrm{KCl} 0,1 \mathrm{M}+10 \mu \mathrm{L} \mathrm{Pb}\left(\mathrm{NO}_{3}\right)_{2} 1000 \mathrm{mg} / \mathrm{L}$ with scan rate $50 \mathrm{mV} / \mathrm{sec}$. Figure $1 \mathrm{~A}$ shows the cyclic voltammogram in $\mathrm{KCl} 0.1 \mathrm{M}$. Figure 1B shows the cyclic voltammogram of $\mathrm{KCl} 0,1 \mathrm{M}+10 \mu \mathrm{L} \mathrm{Pb}\left(\mathrm{NO}_{3}\right)_{2} 1000 \mathrm{mg} / \mathrm{L}$. For a reversible system (Figure 1B), the (Mehta and Sindal 2010). separation of anodic peak potential and cathodic peak potentials of the couple is $57 / \mathrm{n}$ $\mathrm{mV}$ and the formal electrode potential is the average of thetwo peak potentials to a good approximation. If electron transfer reaction is irreversible system, then peak to peak distance is large whereas in reversible system, the peak to peak distance is short

$$
\text { (Mehta and Sindal 2010). }
$$

(1)




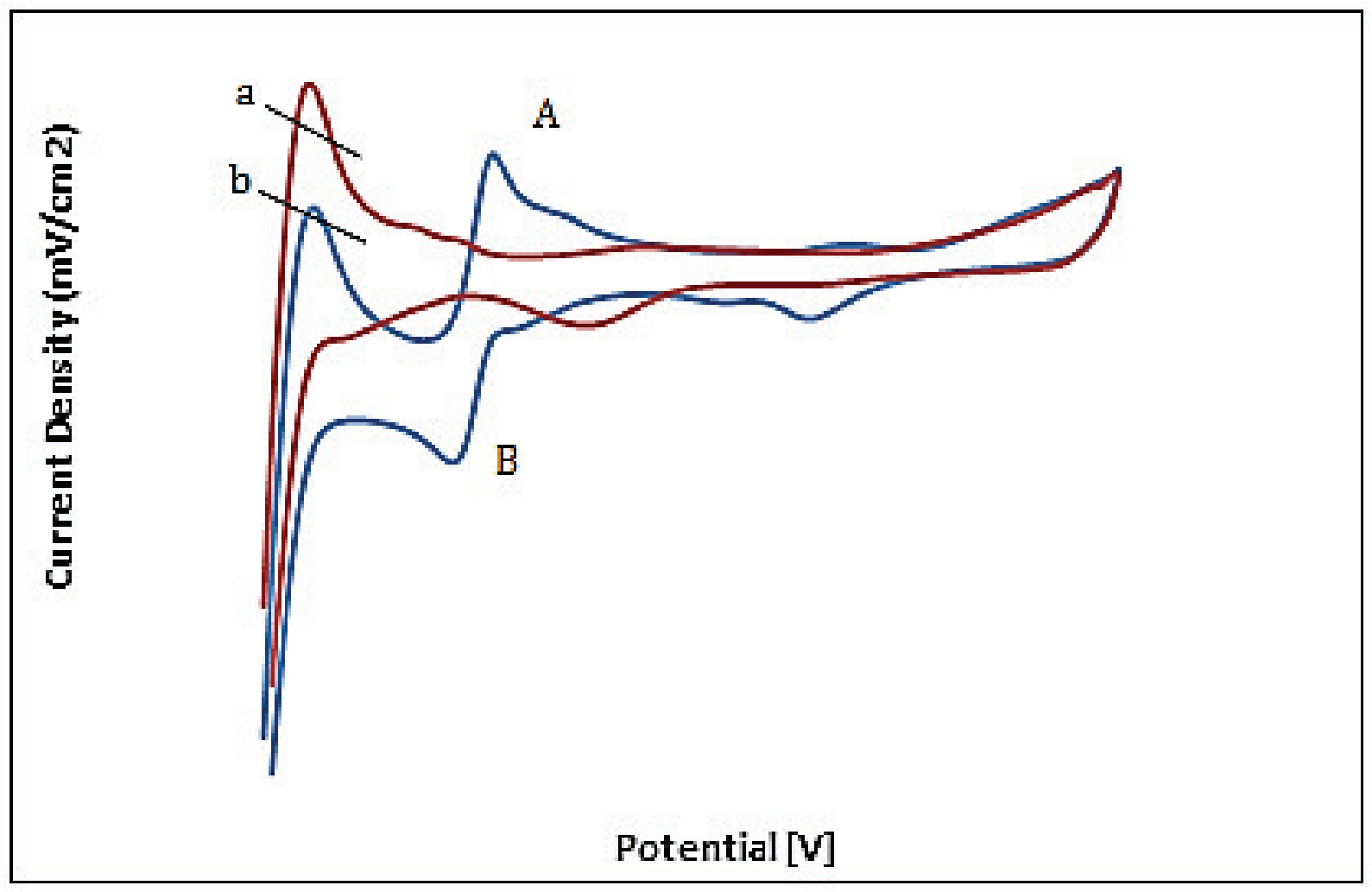

Figure 2. Cyclic voltammograms using $\mathrm{Pt}$ wire electrode for (a) $\mathrm{KCl} 0.1 \mathrm{M}$ without $\mathrm{Pb}\left(\mathrm{NO}_{3}\right)_{2}$ and (b) $\mathrm{KCl} 0.1 \mathrm{M}+10 \mu \mathrm{L} \mathrm{Pb}\left(\mathrm{NO}_{3}\right)_{2} 1000 \mathrm{mg} / \mathrm{Lw}$ ith scan rate $50 \mathrm{mV} / \mathrm{sec}$.

Figure 2 shows overlay of the cyclic Autolab), a Pt plate counter electrode, and an voltammograms using $\mathrm{Pt}$ wire electrode for $\mathrm{Ag} / \mathrm{AgCl}$ reference electrode (saturated with (a) $\mathrm{KCl} \mathrm{0,1} \mathrm{M}$ without $\mathrm{Pb}\left(\mathrm{NO}_{3}\right)_{2}$ and (b) $\left.\mathrm{KCl} \mathrm{KCl}\right)$. The potential was swept in inverse $0.1 \mathrm{M}+10 \mu \mathrm{L} \mathrm{Pb}\left(\mathrm{NO}_{3}\right)_{2} 1000 \mathrm{mg} / \mathrm{L}$. The A scanning mode starting from -1.0 to $1.0 \mathrm{~V}$ peak at Figure $2 \mathrm{~b}$ shows the oxidization peak with a scanning rate of $50 \mathrm{mV} / \mathrm{s}$. Figure 2 of $\mathrm{Pb}$, when added $\mathrm{Pb}^{2+}$ increasing current shows the anodic peak potential $\left(E_{p a}\right)$ and density at A peak was observed. The B peak peak current $\left(i_{p a}\right)$ (peak A), from peak B at Figure $2 \mathrm{~b}$ shows the reduction process of arecathodic peak potential $\left(E_{p c}\right)$ and peak $\mathrm{Pb}$ (II) to $\mathrm{Pb}(0)$. Cyclic voltammetry current $\left(i_{p c}\right)$.

measurements were performed in an electrochemical cell with a volumetric capacity of $50 \mathrm{~mL}$ containing a $\mathrm{Pt}$ wire electrode working electrode (Metrohm 


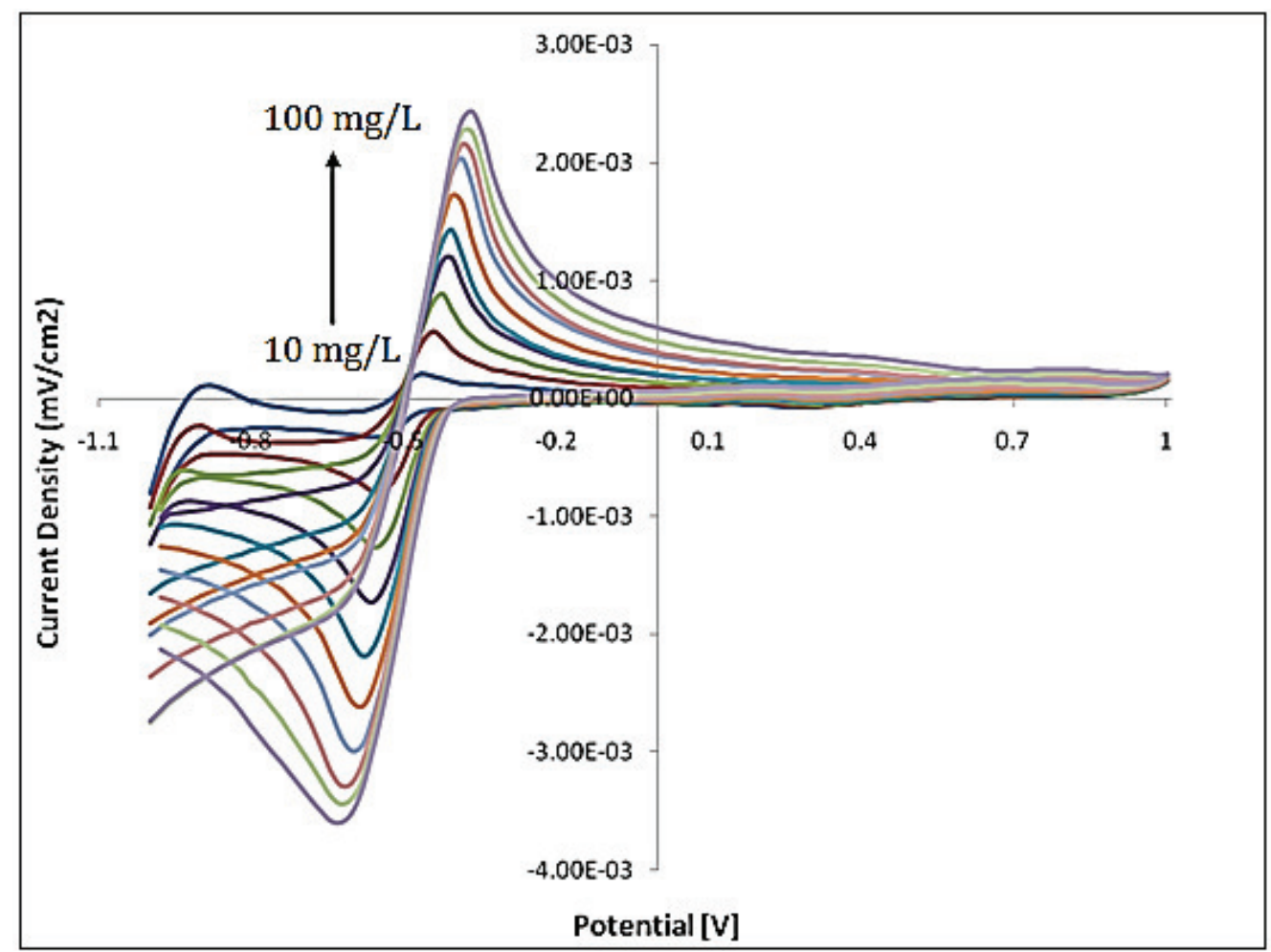

Figure 3. Cyclic voltammograms using Pt wire electrode for $\mathrm{KCl} 0,1 \mathrm{M}+10 \mu \mathrm{L} \mathrm{Pb}\left(\mathrm{NO}_{3}\right)_{2}$ with different concentration $10-100 \mathrm{mg} / \mathrm{L}$ with scan rate $50 \mathrm{mV} / \mathrm{sec}$.

\section{Calibration curve form oxidation peak}

Figure 3 shows the effect of $\mathrm{Pb}^{2+}$ concentration to current density. Figure 4 shows the peak current density increased with increasing of $\mathrm{Pb}^{2+}$ concentration. As it can be seen from Figure 3 there is an increase in oxidation peaks current with the increase in lead concentrations which leads to a linear relation between these two parameters. Figure 4 shows the effect of $\mathrm{Pb}^{2+}$ concentration can be shown by recording the $\mathrm{CV}$ at each concentration (10-100 mg/L) and plotting current density versus concentration for either the anodic peak or the cathodic peak (Figure 4B and 4C). The equation obtained from the linear calibration graph in the studied concentration range for $\mathrm{Pb}$ (II) in aqueous $\mathrm{KCl}$ is (where represents the value of oxidation current and, the value of lead (II) concentrations, expressed as $\mathrm{mg} / \mathrm{L}$ with a correlation coefficient of $\mathrm{R}^{2}=0.997$. Results obtained are shown in (Figure 4). The effect of concentration on the peak current of $\mathrm{Pb}$ was examined from $10 \mathrm{mg} / \mathrm{L}$ to $100 \mathrm{mg} / \mathrm{L}$, the resulted calibration curve showed a linear range from $10 \mathrm{mg} / \mathrm{L}$ to $70 \mathrm{mg} / \mathrm{L}$ with a correlation coefficient of $\mathrm{R}^{2}=0.997$. The limit of detection (LOD) and limit of 
quantification (LOQ) for $\mathrm{Pb}(\mathrm{II})$ was (oxidation peaks) and it was found to be calculated based on calibration curve 3.4039 and $11.3463 \mathrm{mg} / \mathrm{L}$, respectively.
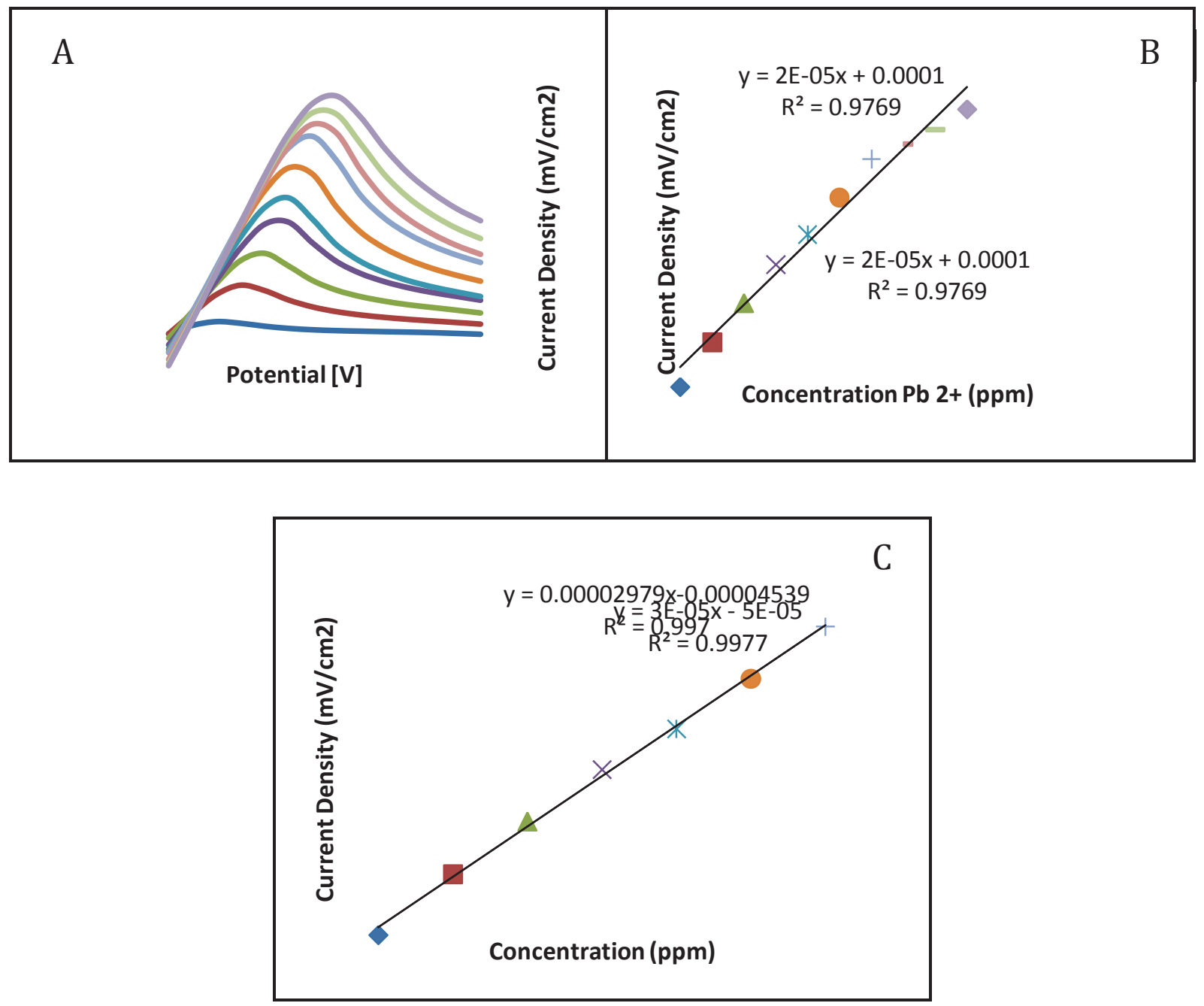

Figure 4. Voltammograms from oxidation peak with different $\mathrm{Pb}^{2+}$ concentrations (from Figure 3) (A), the calibration curve from oxidation peaks, without selected data (B) and the calibration curve from oxidation peaks with selected data (C)

\section{Calibration curve form reduction peak}

Figure 4. Voltammograms from reduction peak (Figure 4A), calibration curve from reduction peaks, without selected data
(Figure 4B) and calibration curve from reduction peaks with selected data (Figure 4C). The relationship between concentration and peak height anodic current was linear 
from 10 to $60 \mathrm{mg} / \mathrm{L}$ of $\mathrm{Pb}^{2+}$. A concentration limit of detection (LOD) and limit of range of 10 to $60 \mathrm{mg} / \mathrm{L}$ of $\mathrm{Pb}^{2+}$ was chosen quantification (LOQ) for $\mathrm{Pb}$ (II) was for calibration curve preparation because in calculated based on calibration curve this range the correlation coefficient was (reduction peaks) and it was found to be almost unity $\left(\mathrm{R}^{2}=0.999\right)$. Base on the 0.9029 and $3.0098 \mathrm{mg} / \mathrm{L}$, respectively. calibration curve form reduction peak, the
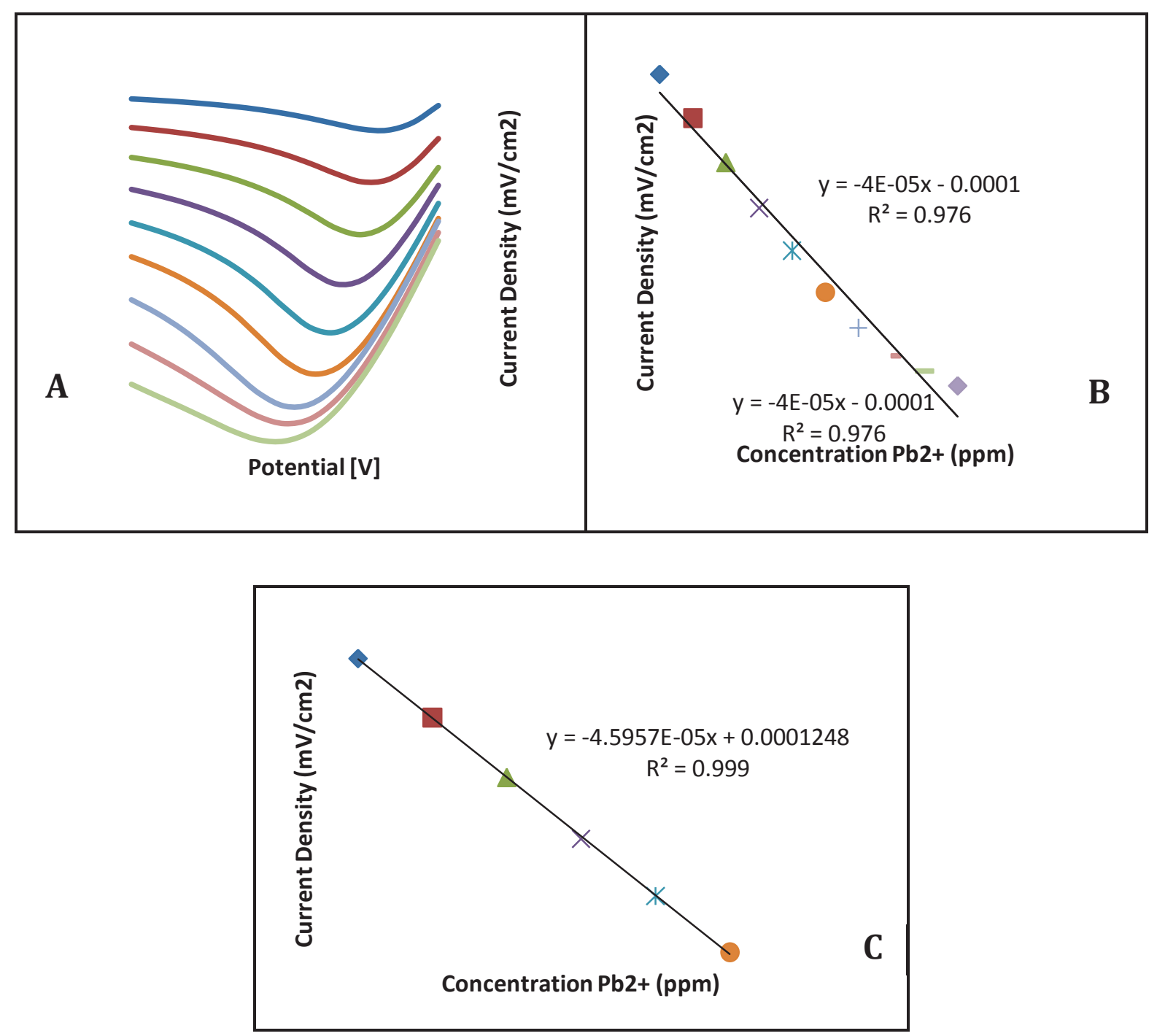

Figure 5. Voltammograms from reduction peak (from Figure 4) (A), calibration curve from reduction peaks, without selected data (B) and calibration curve from reduction peaks with selected data (C) 
Table 1 shows the analytical 0.9994, respectively. For the purpose of parameters of $\mathrm{Pb}$ using voltammogram for analysis, the slope and limit of detectionwere both $E_{p}$ anodic and $E_{p}$ cathodic. From the also determined, where the sensitivity of the calibration curve obtained using both $\mathrm{E}_{\mathrm{p}}$ technique is correctly defined as the slope of anodic and $\mathrm{E}_{\mathrm{p}}$ cathodic, the correlation the calibration curve.

coefficient (r) recorded were 0.9985 and

Table 1. Analytical parameters of $\mathrm{Pb}$ using voltammograms from oxidation and reduction

peaks

\begin{tabular}{lcc}
\hline \multicolumn{1}{c}{ Parameters } & Oxidation peaks $\left(\mathrm{E}_{\mathrm{p}}\right.$ anodic) & Reduction Peaks $\left(\mathrm{E}_{\mathrm{p}}\right.$ cathodic) \\
\hline Equation regression linear & $\mathrm{y}=2.979 .10^{-5} \mathrm{x}-4.539 .10^{-5}$ & $\mathrm{y}=-4.596 .10^{-5} \mathrm{x}+1.248 .10^{-5}$ \\
Slope & $2.979 .10^{-5}$ & $-4.596 .10^{-5}$ \\
Intercept & $-4.539 .10^{-5}$ & $1.248 .10^{-5}$ \\
Correlation coefficient (r) & 0.9985 & 0.9994 \\
Coefficient of determination & 0.9970 & 0.9990 \\
$\left(\mathrm{R}^{2}\right)$ & & \\
Limit of detection (LOD) & $3.4039 \mathrm{mg} / \mathrm{L}$ & $0.9029 \mathrm{mg} / \mathrm{L}$ \\
Limit of quantification (LOQ) & $11.3463 \mathrm{mg} / \mathrm{L}$ & $3.0098 \mathrm{mg} / \mathrm{L}$ \\
\hline
\end{tabular}

The slope for the calibration curve oxidation peaks ( $E_{\mathrm{p}}$ anodic) for the analysis using both $\mathrm{E}_{\mathrm{p}}$ anodic and $\mathrm{E}_{\mathrm{p}}$ cathodic were of $\mathrm{Pb}^{2+}$ using $\mathrm{CV}$ method. Base on LOD and $2.979 .10^{-5}$ and $-4.596 .10^{-5}$, respectively LOQ data the reduction peaks ( $\mathrm{E}_{\mathrm{p}}$ cathodic) (Table 1). From the analytical parameters, it was more sensitive compared to oxidation could be concluded that reduction peaks ( $E_{p}$ peaks ( $E_{p}$ anodic). cathodic) was more sensitive compared to

Table 2. Analytical application of proposed method

\begin{tabular}{clcccc}
\hline No & Wastewater & Pb Concentration in wastewater(mg/L) & $\begin{array}{c}\text { Pb Spike } \\
(\mathrm{mg} / \mathrm{L})\end{array}$ & $\begin{array}{c}\text { Pb } \\
\text { Found } \\
(\mathrm{mg} / \mathrm{L})\end{array}$ & Recovery* (\%) \\
\hline 1 & Sample 1 & 12.54 & 5.0 & 4.91 & 98.2 \\
2 & Sample 2 & 12.78 & 5.0 & 5.22 & 104.4 \\
3 & Sample 3 & 11.98 & 5.0 & 4.97 & 99.4 \\
\hline
\end{tabular}

*Average of three determinations

The LOD is defined as the lowest the background noise with a certain degree of concentration that can be distinguished from confidence. Limit of detection (LOD) and 
limit of quantification (LOQ) are two accurate, precise, reproducible and important performance characteristics in inexpensive with acceptable correlation of method validation. LOD and LOQ are terms used to describe the smallest concentration of an analyte that can be reliably measured by an analytical procedure (UNODC, 2009). LOD and LOQ of the Pt wire electrode using $\mathrm{Pb}^{2+}$ analysis were found to be $0.9029 \mathrm{mg} / \mathrm{L}$ and $3.0098 \mathrm{mg} / \mathrm{L}$, respectively.

Recovery experiments should be performed by comparing the analytical results for extracted samples at three concentrations. Recovery of the analyte need not be $100 \%$, but the extent of recovery of an analyte and of the internal standard should be consistent, precise, and reproducible. Table 2 showed electroanalysis $\mathrm{Pb}^{2+}$ in $0.1 \mathrm{M} \mathrm{KCl}$ solution using Pt wire electrode have a good recovery is close to $100 \%$.

\section{Conclusions}

It was shown that anodic and cathodic peak could be obtained using cyclicvoltammetry method for determination of $\mathrm{Pb}$ in $\mathrm{KCl}$ solution. The oxidation of $\mathrm{Pb}$ on $\mathrm{Pt}$ wire electrode occurs in a reversible system. Analytical parameters from cathodic peak was a better compared to anodic peak for analyzing of $\mathrm{Pb}$ using $\mathrm{CV}$ method. As a conclusion, electroanalysis lead in waste water using platinum wire electrode are

determination $\left(\mathrm{R}^{2}=0.999\right), \mathrm{LOD}=0.9029$ $\mathrm{mg} / \mathrm{L}, \mathrm{LOQ}=3.0098 \mathrm{mg} / \mathrm{L}$ and recovery $=$ $100,67 \%$. The methods can be used for the analysis of lead in waste water. This method is simplicity of sample preparation and use of low cost reagents are the additional benefit.

\section{Acknowledgement}

This research was supported by the Directorate of Research and Community Service, Islamic University of Indonesia (DPPM UII), Yogyakarta, Indonesia through “Hibah Interdisipliner" Research Grant 2013 for the financial support.

\section{References}

Carapuc, H. M., Monterroso, S. C. C., Rocha L. S. and Duarte, A. C., 2004, Simultaneous Determination of Copper and Lead in Seawater Using Optimized Thin-Mercury Film Electrodes in situ Plated in Thiocyanate Media," Talanta, Vol. 64, no. 2, 566-569.

Cui, F., Yun, Y., Hui, G., and Wang, Y., 2012, Determination of Lead at Nanogram Level in Water Samples by Resonance Light Scattering Technique Using Tetrabutyl 
Ammonium Bromide as A Molecular

Probe, Bull. Chem. Soc. Ethiop. Vol. 26, no. $1,1-8$.

David, T.W., Than, M.M and Tun, S., 2003, Lead removal from industrial waters by water hyacinth. $A U J$. T., Vol. 6, no.4, 187-192.

Duran, C. Senturk, H. B. Elci, L. Soylak, M. and Tufekci, M. 2009. Simultaneous preconcentration of $\mathrm{Co}(\mathrm{II}), \mathrm{Ni}(\mathrm{II})$, $\mathrm{Cu}(\mathrm{II}), \quad$ and $\mathrm{Cd}(\mathrm{II})$ from environmental samples on Amberlite XAD-2000 column and determination by FAAS, Journal of Hazardous Materials, Vol. 162, no. 1, 292-299.

Laschi, S., Palchetti, I., and Mascini, M., 2006, Gold-Based Screen-Printed Sensor for Detection of Trace Lead," Sensors and Actuators B: Chemical, Vol. 114, no. 1, 460-465.

Marichamy B., and Ramalakshmi, N., 2013, Heavy Metal ions Detection in real samples by using Polyaniline doped 2,6-bis (4-methyl piperazin-1ylmethyl)-1,4-hydroquinone Wax Impregnated Graphite Electrode, International Journal of Chemical Studies, Vol. 1 no. 3, 142-149.

Mehta, P., and Sindal, R. S. 2010, Cyclic Voltammetric Study of $\mathrm{Pb}$ (II)
Indifferent Sodium Salts as Supporting electrolytes, Int. J. Chem. Sci. Vol. 8, no. 1, 345-350.

Naeem, K. Yawar W., Akhter, P.and Rehana, I. 2012, Atomic absorption spectrometric determination of cadmium and lead in soil after total digestion, Asia-Pacific Journal of Chemical Engineering, Vol. 7, 295301.

Raj, J., Raina, A., Mohineesh and Dogra, T. D. 2013, Direct Determination of Zinc, Cadmium, Lead, Copper Metal in Tap Water of Delhi (India) by Anodic Stripping Voltammetry Technique. Proceedings of the $16^{\text {th }}$ International Conference on Heavy Metals in the Environment. Rome, Italy.

Singh, D., Tiwari, A., and Gupta, R., 2012, Phytoremediation of lead from astewater using aquatic plants, Journal of gricultural Technology, Vol. 8, no.1, 1-11.

Srivastav, R. K. Gupta, S. K. Nigam K. D. P. and Vasudevan, P. 1994, Treatment of Chromium and Nickel in Wastewater by Using Aquatic Plants, Water Research, Vol. 28, no. 7, 16311638. 
United Nations Office on Drugs and Crime (UNODC), 2009. Guidance for the Validation of Analytical Methodology and Calibration of Equipment used for Testing of Illicit Drugs in Seized Materials and Biological Specimens, Laboratory and Scientific Section, United Nation, New York.

United States Environmental Protection Agency (U.S. EPA ), 2002, National Reco- mmended Water Quality Criteria, Office of Water EPA-822-R02-047 Environmental Protection Office of Science and Technology.

Voica, C. Kovacs, M. H. Dehelean, A. Ristoiu D. and Iordache A. 2012, ICP-MS Determinations of Heavy Metals in Surface Waters from Transylvania, Rom. Journ. Phys., Vol. 57, No. 7-8, 1184-1193.

World Health Organization (WHO), 2004, Drinking water quality, Guidelines for third edition, Volume 1, Geneva.

Zen, J.M., Yang, C.C., and Kumar, A.S., 2002, Voltammetric behavior and trace determination of $\mathrm{Pb}^{2+}$ at a mercury-free screen-printed silver electrode, Analytica Chimica Acta, Vol. 464, 229-235. 